\title{
Designing Learning Trajectory on The Topic of Simplifying Fractions Using Realistic Mathematics Education with Flipped Classroom Strategy
}

\author{
Stevanus Trionanda ${ }^{1, *}$ Hongki Julie ${ }^{1}$

\begin{abstract}
${ }^{1}$ Departement of Mathematics Education, Magister Program of Universitas Sanata Dharma Yogyakarta, Indonesia *Corresponding author. Email: stevanustrionanda23@gmail.com
\end{abstract}

\begin{abstract}
This study aims to design a learning trajectory-based instruction that is used to teach simplification of fractions using realistic mathematic education and flipped classroom. This study is the design research which aims to develop a learning instrument theoretically and empirically. The instruments used are daily notes, learning trajectory, and learning video. The learning trajectory consists of goals and learning assumptions, activities of teacher and students, and students' flow of thought. Because the data is qualitative, the retrospective analysis will be done using Miles-Huberman method which consists of data collection, data display, data reduction, and conclusion drawing. The result of this study is a trajectorybased instruction using realistic mathematics education and flipped classroom that is used to teach simplification of fractions. The phases of the trajectory-based instruction are as follows: 1) pre-phase where teachers gave rules to be followed by students during class, 2) self-study phase where students learn from the video and solve problems in it before going to the next phase, 3) synchronous learning phase where students, facilitated by teacher solve realistic problems about fraction simplification by WhatsApp and continued by Zoom, 4) transfer phase where students apply their knowledge by doing exercise and small projects.
\end{abstract}

Keywords: Design research, Realistic mathematics education, Flipped classroom, Fractions.

\section{INTRODUCTION}

The spread of Covid-19 has changed many aspects of our lives in recent years. Because of this Indonesian government have tried their best efforts to suppress the spread of Covid-19 from CARE, vaccinations, and social distancing has become the new norm of society to prevent the spread of Covid-19. This in turn also affects learning from face-to-face learning to distance learning and it also means it changes how materials are presented and taught. Subjects like mathematics is also heavily impacted because being an abstract subject mathematics need more interaction between students to their teacher, friends, and interactives and not being able to interact with it, made students unable to form good mathematics skills [1]. Even before the pandemic, based on research by Rohmah shows that $30(90 \%)$ students fail to answer a non-routine question about simplifying fraction. The reason this happens stems from the lack of definition of fraction and instead focuses more on procedural skills (didactical obstacle) and lack of context of knowledge that students have are unable to understand and use information in questions in order to solve problems (epistemological obstacle)[2].
That is why there is a need to design a learning trajectory-based instruction that can be implemented from a distance so students in turn can form good mathematical skills. Realistic Mathematics Education is chosen to be an approach in designing the learning trajectory-based instruction because of its' idea which mathematical activities are human activities that have human values, are connected to reality, are in the student's experience, and are relevant to society [3]. This is done by phenomenology exploration, mathematization, using students' construction, interactivity, and intertwinement characteristic in learning mathematics[4]. There is a clear relationship between RME and learning fractions where by using students' constructions students learn to define the meaning of their lesson and phenomenological exploration where students solve problems that can be experienced by students so students are able to understand the problem and use the information on the problem to solve non-routine questions. Although a trajectory-based instruction using RME can be designed, however due to distance learning, interactivity characteristic which is defined by Treffers [4] as a characteristic which involves students to consult with their friends and teachers while working on a task, present their work, and evaluate their 
work collectively is harder to do. This is because students and teachers need to be there at the same time, yet doing synchronous learning all the time would strain the parents' budget [1].

In order to prevent the loss of RME characteristics and not strain parents' budget, researcher suggest to implement flipped classroom and RME as a basis to design a learning trajectory-based instruction. Flipped classroom is chosen because it can leverage characteristics of RME based on Voight [5] and not strain budget by dividing process of learning into pre-phase, self-learning phase, synchronous learning, and transfer phase [6]. Based on this background, this paper aims to design a trajectory-based instruction that is used to teach simplification of fractions using realistic mathematic education and flipped classroom.

\section{METHODS}

Based on the goals stated, this research aims to design a learning trajectory-based instruction on the topic of simplifying fractions using realistic mathematics education and flipped classroom strategy. In order to do so, an approach need to be chosen as a way to design said learning trajectory-based instruction. Design research approach is chosen as the approach based on its' aim according to Van den Akker [7] which is to design intervention or trajectory such as strategy, material, product, or system as a solution to complex education issues. Design research is chosen because of its' aim to design intervention or trajectory as a solution to complex education problems which aligns with this research aims to improve students' mathematical skills in simplifying fractions while learning from a distance by designing a learning trajectory-based instruction on the topic of simplifying fractions using realistic mathematics education and flipped classroom strategy.

The steps of design an instrument using this approach is as follows [8]:

1. Preparation and design where researcher gather and make activities that have potential in designing hypothetical learning trajectory for trajectory-based instruction.

2. Teaching experiment where researcher implements the trajectory-based instruction which has been designed on students. Where in this research the students or the subjects are 28 grade IVA and IVB students of Tanjungpinang Catholic Elementary School.

3. Retrospective analysis where researcher compared students' learning and hypothetical learning trajectory.

\section{RESULTS AND DISCUSSION}

The assessment on the students' prior basic competencies is that the students have learnt about the meaning of fractions as a part of whole and as a division and equivalent fractions based on the revised curriculum of 2013. The results are as follow:
1. Grade 3

a. Explaining whole numbers and simple proper fractions such as $(1 / 2,1 / 3$, and $1 / 4)$ using number line.

b. Generalize idea of fractions as a part of a whole using concrete objects.

c. Explain the idea of addition and subtraction fractions with equal denominators and solve problems related to addition and subtraction of fractions with equal denominators.

2. Grade 4

a. Explaining equivalent fractions using pictures and concrete objects.

The basic competencies that students needed to have associated with simplification of fraction on the 2013 revision curriculum are as follows:

3. Grade 4

a. Identifying different types of fractions (proper, mixed, decimal, and percent) and the connections between them.

4. Grade 5

a. Explaining and doing addition and subtraction of fraction with different denominators.

b. Explaining and doing multiplication and division of fractions and decimals.

5. Grade 6

a. Explaining and doing number operations involving whole numbers, fractions, and/or decimals in different forms according to order of operations.

\subsection{Learning Trajectory-based Instruction}

The final product of learning trajectory-based instruction after teaching experiments and retrospective analysis is presented as follows:

\section{Pre-phase}

In this phase teacher explains what students are going to do during lessons.

a. Learning phases will be divided into three phases which are self-learning phase, synchronous learning phase through WhatsApp to discuss answers and zoom to present students' answers, and transfer phase.

b. In self-learning phase students are given video materials about equivalent fractions before using knowledge of equivalent fraction to form an understanding of simplifying fractions during synchronous learning phase.

c. In synchronized learning phase, teacher will divide learning session into two sessions which is class discussion using WhatsApp and continued by zoom to present answers of from class discussion.

d. In transfer phase the teacher will give students task to be collected after two days it is given, students 
can ask teacher and discuss with their friends if there are problems that they don't understand.

2. Self-learning phase

a. The teacher explains the goal of self-learning phase which is learning about equivalent fractions through learning video.

b. The content of the video is as follows

1) Problem 1

(a)

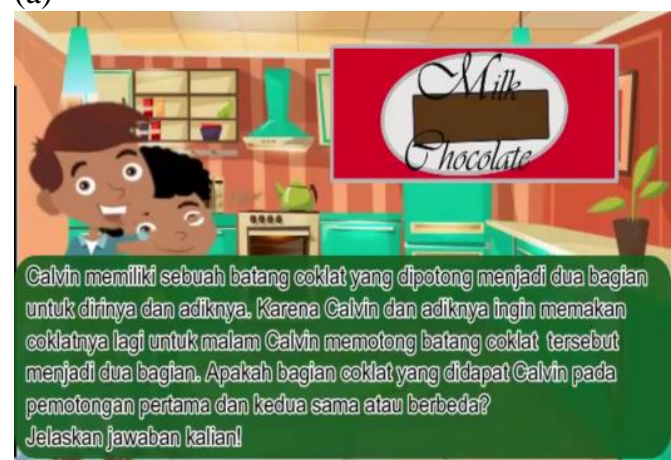

(b)

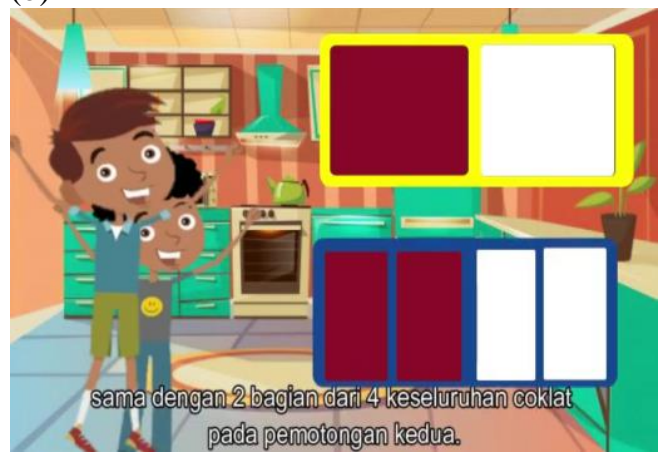

Figure 1 (a) Problem about Equivalent Fractions (b) The Solution to the answer

Figure 1a explains a problem about equivalent fractions where Calvin has a bar of chocolate that is cut into 2 pieces for himself and his brother. Calvin and his brother want to eat the chocolate again for dinner, so he cut each piece into two pieces. Are the pieces of chocolate obtained from first cut and second cut the same? Figure $1 \mathrm{~b}$ explains that the pieces are the same because first cut which is 1 part of 2 whole is the same size as the 2 parts of 4 whole from the second cut and could be written as $1 / 2=2 / 4$

\section{2) Problem 2}

(a)

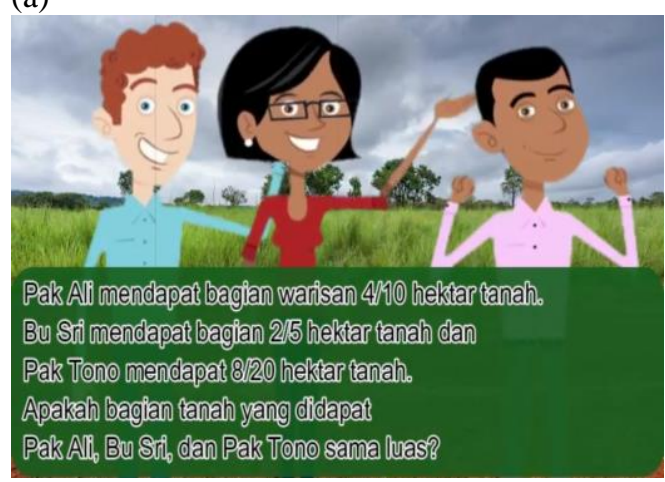

(b)

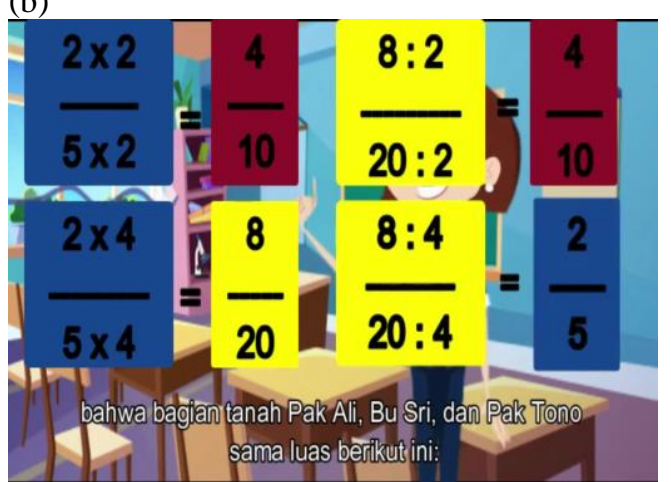

Figure 2 (a) Problem about Equivalent Fractions (b) The Solution to the answer

Figure $2 \mathrm{a}$ explains a problem about equivalent fractions where Mr. Ali, Mrs. Sri, and Mr. Tono each gets a plot of land from their parents. Mr. Ali gets 4/10 of land, Mrs. Sri gets $2 / 5$ of land, and Mr. Tono gets $8 / 20$. Are the lands owned by Mr. Ali, Mrs. Sri, and Mr. Tono equal? Figure $1 \mathrm{~b}$ explains that each plot of land owned by Mr. Ali, Mrs. Sri, and Mr. Tono is equal because when you divide the nominator and denominator of Mr. Ali's plot by 2 will be the same as Mrs. Sri and when you multiply the nominator and denominator of Mr. Ali's plot by 2 will be the same as Mr. Tono. And the results can be made as:

$$
\frac{2}{5}=\frac{4}{10}=\frac{8}{20}
$$

c. The students are then informed to work on a task before synchronous learning phase.

A fabric shop sells rolls of fabric in 3 different cuts, first cut is by dividing fabric into 5 cuts, second cut is by dividing fabric into 10 cuts, and third cut is by dividing fabric into 15 cuts. Sinta wants to buy two first cut fabric, but the store only has one and has to cut another.

1) Represent the process of cutting a roll of fabric by first cut, second cut, and third cut!

2) Describe how many cuts of fabric from second cut is equal to one cut of fabric from first cut!

3) Describe how many cuts of fabric from third cut is equal to one cut of fabric from first cut!

4) From the problem it is known that first cut of fabric is not available, so how many cuts from fabric cut by second cut or third cut so it is equal to the number of fabrics Sinta needed?

5) Why is the number of fabrics that you choose equal to the number of fabrics Sinta needed?

d. The students are encouraged to try to work on the task given by themselves before ending the video.

e. The video is an attempt to bring out the characteristics of phenomenological exploration where students are given problems with realistic context, mathematization by translating context problems into mathematic problems then solving them and translating them back, using students' contribution and intertwinement by solving questions are used to train students' abilities in solving math problem which is also found in 
research by Putra and Suparman, and also Handayani about developing RME learning video $[9,10]$.

3. Synchronous Learning Phase

a. The teacher explains the goal of synchronous learning phase which is to understand simplification of fractions.

b. The teacher and students review the self-learning phase.

1) The teacher asks the students to send photos of their process to try and solve the problems given in the video and asked them to explain their work.

2) If there are no students that send their pictures or explain his/her work the teacher will point and ask one of the students about their idea on the problem.

3) The teacher asks other students whether they agree or disagree with the opinion and ask students to state the reasons for agreeing or disagreeing with their friend's opinion.

4) If all students state that they have difficulty in answering, the teacher will immediately guide the class in solving problems.

5) Discussion continues until problems are answered.

This is an attempt to bring out the characteristic of using students' contributions where students use and present their findings which is also found in Sabon and Julie [11] and interactivity in RME where students share their findings and both teacher and student discuss the solution of the problem which is also found in Purwati and Sabon and Julie[11,12].

c. Problem Exploration 1:

1) The teacher gives the problem below and asks students to discuss how to solve the problem in WhatsApp.

From previous findings, you have discovered that equivalent fractions can be made by multiplying or dividing the numerator and denominator by the same number.

i. Write down as many fractions as possible that are equivalent to $8 / 12$ and determine which of these equivalent fractions have numerator and denominator that cannot be divided any number other than 1 .

ii. Write down as many fractions equal to 24/30 as possible and determine which of these equivalent fractions have numerator and denominator that cannot be divided by any number other than 1 .

iii. Describe the process you used to find an equivalent fraction whose numerator and denominator cannot be divided other than 1.

2) The teacher gives out a division table to help students to help students that have trouble with division.
3) The teacher asks students to ask what has been understood from the problem and the students are given time to understand the problem given by the teacher. Students are also given the opportunity to ask questions if students have difficulty understanding the problems given by the teacher.

4) If students say they have difficulty in solving the problem, they can be helped by the following process.

i. Students are asked about their knowledge of finding equivalent fractions.

ii. If students can answer, students are asked in order to make smaller equivalent fractions do they need to multiply or divide the nominators and denominators of the fractions.

iii. If students can answer, students are told to use the division table to find what number that can divide both nominator and denominator and divide the nominators and denominators using said number.

iv. If students can answer and their answer shows that the nominators and denominators are still divisible, students are asked to find what other number that can divide both nominator and denominator and divide the nominators and denominators using said number; this process continues until the nominators and denominators are no longer divisible.

v. If students said that the fractions are no longer divisible, the teacher applaud students for their effort and told them to write the process of finding equivalent fractions whose numerator and denominator cannot be divided other than 1 in the third question.

Problem exploration activity is done in order to bring out phenomenology exploration characteristic in RME by giving realistic context problems for students to explore which is also found in Handayani [10], mathematization process characteristics of RME where students and teacher discuss strategy to solve the problem which is also found in Sabon and Julie [11], interactivity characteristics in RME where students can build their own knowledge through interaction between teachers and students and intertwinement characteristics of RME where mathematical structures and concepts are interrelated which is also found in Purwati [12], and in the case of this research the intertwinement is equal fractions and simplifying fractions.

d. Class Discussion

1) The teacher leads class discussion in Zoom to discuss the student's answers by first asking if any of the students that present their ideas from earlier discussion.

2) The students' expected answer are as follows: 
For the first and second questions, students wrote some fractions by multiplying or dividing nominator and denominator of $8 / 12$ by some number, or just divide the nominator and denominator by some number over and over again until both nominator and denominator of the equivalent fractions cannot be divided by 1 .

$$
\frac{8}{12}=\frac{8 \div 2}{12 \div 2}=\frac{4 \div 2}{6 \div 2}=\frac{2}{3}
$$

From equation (1) students can find that because $2 / 3$ cannot be divided by any number other than $1,2 / 3$ is an equivalent fraction of $8 / 12$ that have the numerator and denominator that cannot be divided any number other than 1 .

For the second question, they follow the rules they found in first question and answer by doing the following process:

$$
\frac{24}{30}=\frac{24 \div 2}{30 \div 2}=\frac{12 \div 3}{15 \div 3}=\frac{4}{5}
$$

From equation (2) students can find that because $4 / 5$ cannot be divided by any number other than $1,4 / 5$ is an equivalent fraction of $4 / 5$ that have the numerator and denominator that cannot be divided any number other than 1 .

For the third question students, wrote the process in order to find an equivalent fraction whose numerator and denominator cannot be divided by a number other than 1 which is by dividing the numerator and denominator of the fraction with a number and repeat this action until no number can divide the numerator and denominator other than 1 .

3) The teacher asks students to respond whether they agree or disagree to the student's presented work.

4) The teacher handles the class discussion and guides the discussion so that students can conclude that simplifying fractions can be done by dividing the nominator and denominator with a number and repeating it again by diving it with same or different number, until it is no longer divisible by any number other than 1 .

Class discussion is done in order to bring out mathematization process characteristics of RME where students and teacher discuss strategy to solve the problem, using students' construction where students use and present their findings, and interactivity where every student share their findings and discuss the solution for the problem. These findings are also found in Sabon and Julie [11]

e. Problem Exploration 2:

1) The teacher gives the problem below and asks students to discuss how to solve the problem in WhatsApp.
Cinema XXI has 320 seats that can be occupied on weekdays before the pandemic. However, based on government regulations during the pandemic, the capacity of cinemas that can be filled by spectators is at most half of the usual capacity. If in a film screening, seats in the cinema are filled with 160 people, has the cinema complied with government regulations?

2) The teacher asks students to ask what has been understood from the problem and the students are given time to understand the problem given by the teacher. Students are also given the opportunity to ask questions if students have difficulty understanding the problems given by the teacher.

3) If students say they have difficulty in solving the problem, they can be helped by the following process.

i. Students are asked about their knowledge of making fractions from real life.

ii. If students can answer, students are asked to make fractions from the number of seats after and before pandemic.

iii. If students can answer, students are told to use their new findings about simplification of fractions which is done by dividing the nominator and denominator with a number and repeating it again by diving it with same or different number, until it is no longer divisible by any number other than 1 and then see if the fraction obtain equals, less than, or more than the recommended amount of people allowed.

Problem exploration activity is done in order to bring out phenomenology exploration characteristic in RME by giving realistic context problems for students to explore which is also found in Handayani [10], mathematization process characteristics of RME where students and teacher discuss strategy to solve the problem which is also found in Sabon and Julie [11], interactivity characteristics in RME where students can build their own knowledge through interaction between teachers and students and intertwinement characteristics of RME where mathematical structures and concepts are interrelated which is also found in Purwati [12], and in the case of this research the intertwinement is equal fractions and simplifying fractions.

f. Class Discussion

1) The teacher leads class discussion in Zoom to discuss the student's answers by first asking if any of the students that present their ideas from earlier discussion.

2) The students' expected answer are as follows: The students' answer by making fraction from the chair capacity after and before the pandemic which is $160 / 320$. Then simplify it using their findings about simplification of fractions by writing

$$
\frac{160}{320}=\frac{160 \div 160}{320 \div 160}=\frac{1}{2}
$$


and then write that the Cinema obeyed government regulations because $160 / 320$ is equal to $1 / 2$ which is half of the capacity of usual capacity of Cinema.

3) The teacher asks students to respond whether they agree or disagree to the student's presented work.

4) The teacher handles the class discussion and guides the discussion so that students can conclude that the cinema problem can be done by making a fraction from the number of seats after the pandemic and before the pandemic (the full capacity of the cinema) which is $160 / 320$ then simplify the fractions until $1 / 2$ is obtained, and then conclude that the Cinema obeyed government regulations because $160 / 320$ is equal to $1 / 2$ which is half of the capacity of usual capacity of Cinema.

Class discussion is done in order to bring out mathematization process characteristics of RME where students and teacher discuss strategy to solve the problem, using students' construction where students use and present their findings, and interactivity where every student share their findings and discuss the solution for the problem. These findings are also found in Sabon and Julie [11].

\section{4. $\quad$ Transfer Phase}

a. The teacher and students conclude today's learning outcomes by answering the following questions:

1) How do you simplify fractions?

Fraction simplification can be done by dividing the numerator and denominator by a number and repeated using the same or different number until the numerator and denominator cannot be divided by numbers other than 1 .

2) Can we simplify fractions by dividing the numerator and denominator by different numbers?

No, because the result will not form an equivalent fraction.

By posing summary questions and then discuss the conclusion of the lesson, this activity brings out using students' construction and interactivity characteristics of RME [13].

b. The teacher gives an exercise from for students to work on.

1) Find 3 fractions that are equivalent to the following fractions.
i. $1 / 2$
ii. $9 / 12$
iii. $1 / 5$ iv. $10 / 14$

1) Simplify the following fractions to the simplest fraction.

i. $8 / 56$ ii. $20 / 35$ iii. $13 / 52$ iv. $10 / 14$

c. The teacher gives a project task to do at home.

Make 3 illustrations that show the process of simplifying fractions with the examples below:

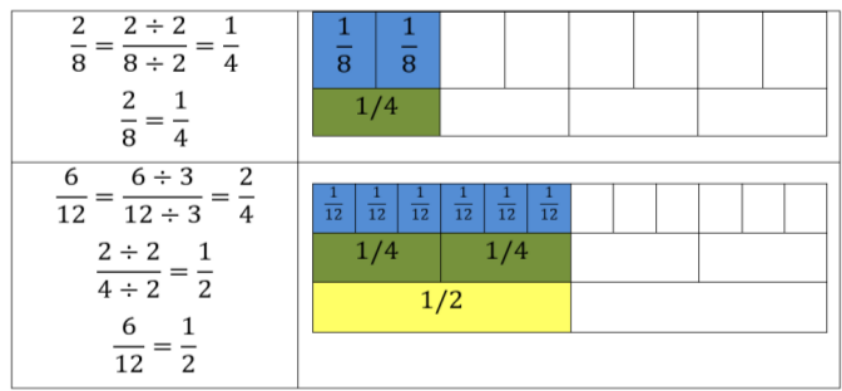

Figure 3 Example of simplification process

\subsection{Teaching Experiment Results}

The teaching experiment was conducted in class $4 \mathrm{~A}$ and $4 \mathrm{~B}$ both consisting of 28 students with class $4 \mathrm{~B}$ as the first experiment class and $4 \mathrm{~A}$ as the second experiment class. At the beginning of the self-learning phase, students in WhatsApp group are asked to watch the video about equivalent fractions and answer questions from the video. During synchronous learning phase, they were given the chance to solve the initial problem and ask the teacher if they cannot solve the problem. The figure 4 below shows that both classes can solve the problem listed.

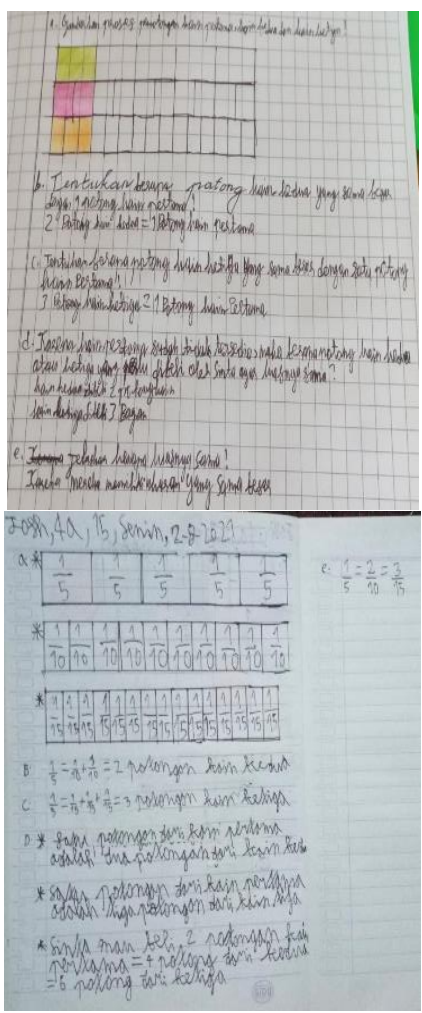

Figure 4 First and Second-class students' answer to selflearning phase problem

After asking the shown students' work idea and discussion so every student get the answer, the teacher gave problem exploration 1 for students to work on.

During the first experiment no division table was given, and when asked questions to lead them to divide most of the students have a hard time doing division so 
the teacher and student together solve the questions given. During the second experiment a division table was given, and when asked questions to lead them to divide most of the students successfully found the numbers needed in order to simplify $8 / 12$ and $24 / 30$ and deduct that in order to find an equivalent fraction of a fraction where the nominator and the denominator cannot be divided by 1 is by dividing the nominator and the denominator of a fraction with a number and done repeatedly.

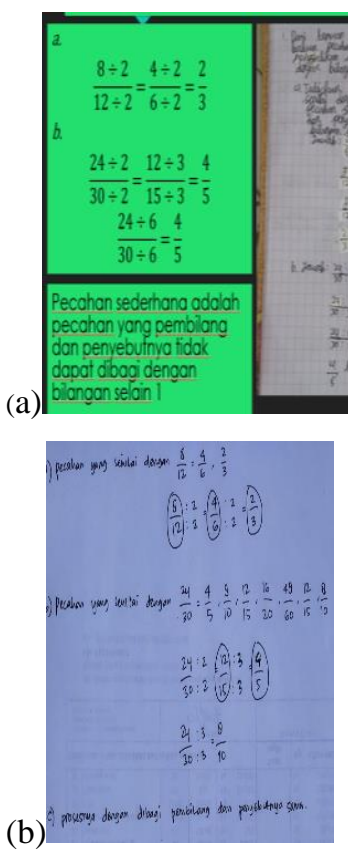

Figure 5 (a) First class answer to problem exploration 1 (b) Second class student answer to problem exploration

Because during the first teaching experiment students have hard time finding the solution to the first problem, the teacher and student had to finish the second problem together using the process stated above. During the second teaching experiment because there was a division table given to make division easier, there was more time to solve problem exploration 2 although they have the right idea, their results will show that the restaurant have doubled the amount the seats allowed so teacher and student finish the problem together using the process stated above. The results are shown below:

(a)

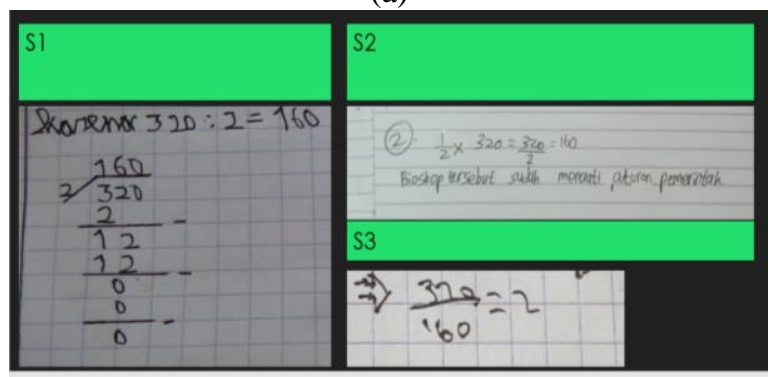

(b)

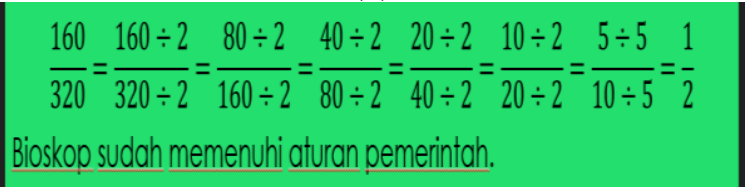

Figure 6. (a) Second class students answer to problem exploration 2 (b) First- and Second-class answer to problem exploration 2

After finishing the class discussion, the teacher and students conclude today's learning by answering questions about what they learned today. The teacher then gives students a task for them to do and tell them to ask any question if they still have problems regarding the lesson before closing today's lesson.

\subsection{Retrospective analysis}

Based on the teaching experiment it is can be concluded that the LTBI that has been made can facilitate student difficulties when trying to solve problem exploration 1 and problem exploration 2. However, based on students' answer there is still some need to facilitate problem exploration 2 mistake where students divide $320 / 160$ instead of making 160/320. This could be done by asking students what role does 160 and 320 in the fraction because if they divide 320/160 the result is two, which means that the restaurant does not comply with government regulations yet the students said the restaurant comply with the regulations by asking them: "how many seats does it take to be full?" and "If the seats are 320/160 doesn't that mean that the restaurant is having overcapacity of 160 customers because restaurants can only fill 160 ?" By doing so students will think their over answer again and teacher can continue facilitate students until they find the answer.

\section{Conclusion}

This paper aims to develop a learning instrument theoretically and empirically which is a learning trajectory-based instruction using realistic mathematics education and flipped classroom that is used to teach simplification of fractions. The context developed by the researcher in this learning trajectory-based instruction is to help students in learning fraction simplification and finding out the way to simplify fraction by dividing the numerator and denominator of a fraction by a number and repeated using the same or different number until the numerator and denominator cannot be divided by numbers other than 1 . The phases of the trajectory-based instruction are as follows:

1. Pre-phase where teachers gave rules to be followed by students during class.

2. Self-study phase where students learn from the video about equivalent fractions and solve problems in it before going to the next phase.

3. Synchronous learning phase where students, facilitated by teacher solve realistic problems about fraction simplification in problem exploration 1 and 
problem exploration 2 about fraction simplification in WhatsApp and continued in Zoom to discuss students' works and findings before collectively conclude what students have learnt,

4. Transfer phase where students apply their knowledge by doing exercise and small projects.

\section{AUTHORS' CONTRIBUTIONS}

ST carried out the conceptualization, writing, data collecting, and data analysis of the article. HJ reviewed and revised the article as ST's Masters Supervisor.

\section{ACKNOWLEDGEMENT}

The researchers would like to express their gratitude to Sanata Dharma University that has provided funding for this research so it can be published. Furthermore, the researchers would like to thank the committee of SEADR-STEACH in UNESA for the opportunity to present and publish the research report.

\section{REFERENCES}

[1] S. Trionanda, Analisis Kesiapan dan Pelaksanaan Pembelajaran Matematika Jarak Jauh berdasarkan Profil TPACK di SD Katolik Tanjungpinang Tahun Ajaran 2020/2021 Pros. Semin. Nas. Mat. Dan Pendidik. Mat. 6, 2021 69-76

[2] S. K. Rohmah, Analisis Learning Obstacles Siswa Pada Materi Pecahan Kelas IV Sekolah Dasar J. Islam. Prim. Educ. 2, 201912

[3] M. Van den Heuvel-Panhuizen, National Reflections on the Netherlands Didactics of Mathematics Teaching and Learning in the Context of Realistic Mathematics Education (Netherlands: Springer Open), 2020.

[4] A. Treffers, Three Dimensions A Model of Goal and Theory Description in Mathematics Instruction - The Wiskobas Project (Netherlands: D. Reidel Publishing Company), 1978

[5] M. Voight, H. Fredriksen, R. Rasmussen, Leveraging the design heuristics of realistic mathematics education and culturally responsive pedagogy to create a richer flipped classroom calculus curriculum Springer 12, 2020

[6] Y. D. Astuti, Analisis Kemampuan Representasi Mahasiswa S1 Pendidikan Matematika Universitas Sanata Dharma dalam Materi Fungsi Kuadrat Setelah Mengalami Proses Pembelajaran dengan Menggunakan Pendekatan Pendidikan Matematika Realistik dengan Strategi Flipped Classroom (Yogyakarta: Universitas Sanata Dharma), 2021.

[7] J. Van den Akker, B. Bannan, A. E. Kelly, Nieveen N and Plomp T 2013 Educational Design Research: Part A: An introduction (Amsterdam: SLO)

[8] A. Bakker, Design Research in Statistics Education. Utrecht (Netherlands: CD- $\beta$ Press), 2004.

[9] R. P. Putra, S. Suparman, Design of Learning Video Using Realistic Mathematics Education Approaches to Developing the Problem-Solving Ability of Students of Class VII High School Int. Summit Sci. Technol. Humanity ISETH 2018, 2018.

[10] S. D. Handayani, Pembelajaran Matematika di Masa Pandemic Covid-19 berdasarkan Pendekatan Matematika Realistik J. Math Educ. Nusant, 6, 2020 179-89

[11] Z. A. K. W. Sabon, H. Julie, Analisis Dampak Pembelajaran Matematika Realistik terhadap Pembelajaran Daring Via WhatsApp Group pada Materi Permutasi Asimtot J. Kependidikan Mat. 3, 2021, 77-84

[12] R. Purwati, Application of Realistic Mathematic Education (RME) Approach in learning Mathematic to Improve Student Learning Outcomes Int. Conf. Elem. Educ, 2, 2020, 729-36

[13] R. K. Sembiring, S. Hadi, M. Dolk, Reforming mathematics learning in Indonesian classrooms through RME ZDM Math. Edu, 40, 2008, 927-39 